Article

\title{
The Role of Rare Earth Lanthanum Oxide in Polymeric Matrix Brake Composites to Replace Copper
}

\author{
Kaikui Zheng ${ }^{1,2}$, Chenghui Gao ${ }^{1, *}$, Fushan $\mathrm{He}^{1}$ and Youxi Lin ${ }^{1}$ \\ 1 School of Mechanical Engineering and Automation, Fuzhou University, Fuzhou 350116, China; \\ kuikui@fzu.edu.cn (K.Z.); hfshan@fzu.edu.cn (F.H.); lyx@fzu.edu.cn (Y.L.) \\ 2 Mechanical and Electrical Engineering Practice Center, Fuzhou University, Fuzhou 350116, China \\ * Correspondence: gch@fzu.edu.cn; Tel.: +86-0591-2286-6810
}

Received: 3 August 2018; Accepted: 12 September 2018; Published: 14 September 2018

\begin{abstract}
The main focus of current research in polymeric matrix brake composites is on searching out a replacement for copper, which has been recently proved to be a hazard to human health and the environment. In this paper, rare earth lanthanum oxide was explored for the replacement of copper in composites. The mechanism of the role of lanthanum oxide in brake composites to replace copper was analyzed. Four series of polymeric matrix brake composites with various amounts of copper (15, $10,5$ and $0 \mathrm{wt} \%)$ and rare earth lanthanum oxide $(0,5,10$ and $15 \mathrm{wt} \%)$ were developed, in which the copper was gradually replaced by lanthanum oxide in the formula. These series were characterized in terms of physical, thermo-physical and mechanical properties. The results show that lanthanum oxide can be successfully used as a replacement for copper in brake composites. Brake composites with $15 \mathrm{wt} \%$ lanthanum oxide that are copper-free are considered optimal, where tribo-properties are considered best. Compared with the addition of copper in brake composites, lanthanum oxide is more conducive to the formation of compacted friction films and transfer films, which is beneficial to the tribological properties of the brake composites. The addition of $\mathrm{La}_{2} \mathrm{O}_{3}$ to the brake composites can cause the reaction between $\mathrm{La}_{2} \mathrm{O}_{3}$ and $\mathrm{Al}_{2} \mathrm{O}_{3}$ to form $\mathrm{LaAlO}_{3}$, and the reaction between $\mathrm{Al}_{2} \mathrm{O}_{3}$ and $\mathrm{BaSO}_{4}$ can produce $\mathrm{Ba}_{18} \mathrm{Al}_{12} \mathrm{O}_{36}$ and $\mathrm{Al}_{2} \mathrm{SO}_{4}$ during the friction and wear processes, which can effectively improve the tribological properties of the brake composites at elevated temperature. This research was contributive to the copper-free, metal-free and eco-friendly brake composites.
\end{abstract}

Keywords: rare earth; lanthanum oxide; copper; polymeric; brake composites; tribological properties

\section{Introduction}

During braking, the wear debris, which contains several hazardous elements (e.g., copper, lead, zinc, antimony), has been recently proven as a threat to human and aquatic life [1-3]. In 2010, California and Washington State pioneered new laws to restrict copper and other heavy metals in brake pads [4]. With the development of the automobile industry, requirements for safety, comfort and environmental friendliness are highly demanded. The development of copper-free, metal-free and eco-friendly brake composites will be a trend in this field. The non-metallization of the polymeric matrix brake composites must be realized by looking for substitute materials of copper.

Copper is an important component in polymeric matrix brake composites and plays a crucial role in the friction properties of the brake composites. The positive effects of copper on brake composites can be summarized in three aspects. First, copper has high thermal conductivity and can effectively conduct away heat from the friction interface, contributing to the good heat resistance of the brake composites $[5,6]$. Second, copper is often used in the friction material industry as a solid lubricant 
for high-temperature applications that maintain the stability of friction at elevated temperatures $[7,8]$. Third, copper is also known for its good ductility, contributing to the formation of friction films, playing an important role in friction and wear properties [9-11]. Many scholars worldwide are conducting research to develop brake composites formulations without copper, and some achievements have been reached [12-17]. However, most developed copper-free brake composites have weaker friction properties than the copper-containing formulations, and most of them contain one or more types of steel fiber, metal lubricants, metal oxides, etc., which cannot realize polymeric matrix brake composites without metals. Gilardi et al. [18] studied the performance of copper-free brake composites by replacing copper with various types of graphite and reported that different types of graphite and their combined use improved the noise vibration and harshness performance and thermal conductivity of the composites. Aranganathan and Bijwe [19] studied the effect of newly commercially available thermo graphite on the friction properties of copper-free friction materials and concluded that this graphite showed low fade and fluctuations in friction coefficient, but they drastically reduced other friction performance, which were not desirable features. Copper perhaps must be replaced by a combination of ingredients. There has been no single ingredient that can replace copper in brake composites.

Rare earth oxides as inorganic particles are gradually introduced into the preparation of the composites because of their excellent physical and chemical characteristics that improve the properties of many materials. It can be used in composite materials to improve the mechanical properties, interfacial properties, heat resistance, etc. [20-23]. The oxides are allotropes of hexagonal crystals, which are similar to layered structures with high melting points and low hardness, act as a solid lubricant at high temperature [24]. In our previous works $[25,26]$, the effects of rare earth lanthanum oxide on the mechanical and tribological properties of the brake composites were studied. We found that rare earth lanthanum oxide can significantly improve the mechanical and tribological properties of the brake composites. Based on these findings, this paper studies the mechanism of the role of rare earth lanthanum oxide in brake composites by replacing copper with rare earth oxides. Hence, four series of polymeric matrix brake composites with varying amounts of copper and rare earth lanthanum oxide were designed and developed by reducing the content of copper $(15,10,5$ and $0 \mathrm{wt} \%)$ while increasing the corresponding content of lanthanum oxide $(0,5,10$ and $15 \mathrm{wt} \%$ ) to replace copper.

\section{Materials and Methods}

\subsection{Formulation and Designation of Composites}

Rare earth lanthanum oxide $\left(\mathrm{La}_{2} \mathrm{O}_{3}\right)$ was supplied by Foshan blue pigment New Material Co., Ltd. (Foshan, China). Table 1 outlines the details of $\mathrm{La}_{2} \mathrm{O}_{3}$, which were provided by the supplier. $\mathrm{La}_{2} \mathrm{O}_{3}$ powder was examined by scanning electron microscopy (SEM) (Model SUPRA 55, Carl Zeiss AG, Jena, Germany) and energy dispersive spectrometry (EDS) (Model X-Max50, Oxford Instruments Co., Ltd., Oxford, UK) to study the details of the shape, size, and elements, as shown in Figures 1 and 2. Ceramic fibers was supplied by Zhoukou Qifeng Mineral Fibers Co., Ltd. (Zhoukou, China). Table 2 outlines its details, which were provided by the supplier. Cashew nut-shell-liquid-modified phenolic resin was supplied by Sumitomo (Tokyo, Japan). Table 3 outlines its details, which were provided by the supplier. Amongst eight ingredients of the brake composites, except $\mathrm{La}_{2} \mathrm{O}_{3}$, ceramic fibers and phenolic resin, all fillers such as copper $(\mathrm{Cu})$, graphite, alumina, barite and nitrile-butadiene rubber (NBR) powder were procured from a local supplier (Fuzhou Taijiang Pinjie Experimental Instrument Co., Ltd., Fuzhou, China). Table 4 outlines the details of $\mathrm{Cu}$, which were provided by the supplier.

Table 1. Details of $\mathrm{La}_{2} \mathrm{O}_{3}$ used in brake composites.

\begin{tabular}{ccccc}
\hline Property Details & Purity (\%) & Granularity (mesh) & Melting Point $\left({ }^{\circ} \mathrm{C}\right)$ & Density $\left(\mathrm{g} \cdot \mathrm{cm}^{-3}\right)$ \\
\hline Specifications & 99.95 & 200 & 2217 & 6.51 \\
\hline
\end{tabular}




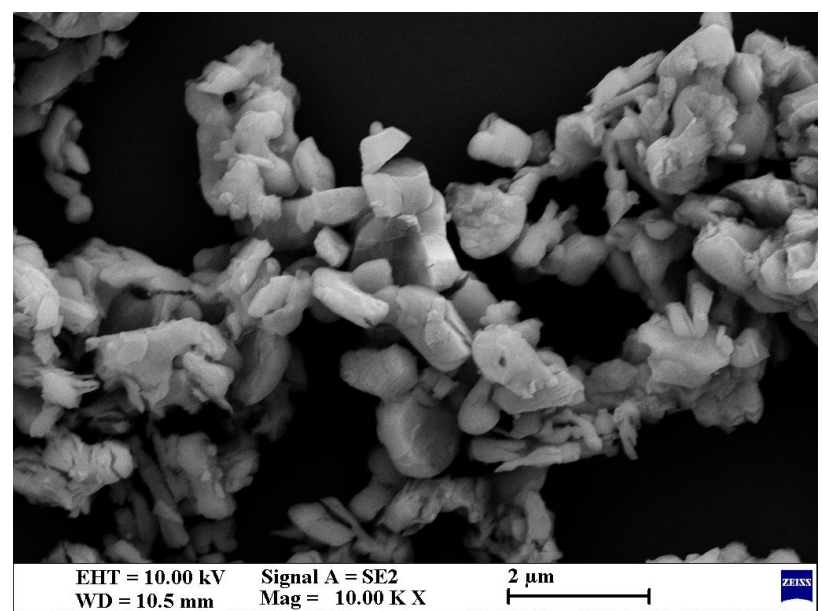

Figure 1. Scanning electron microscope (SEM) micrograph of selected $\mathrm{La}_{2} \mathrm{O}_{3}$.

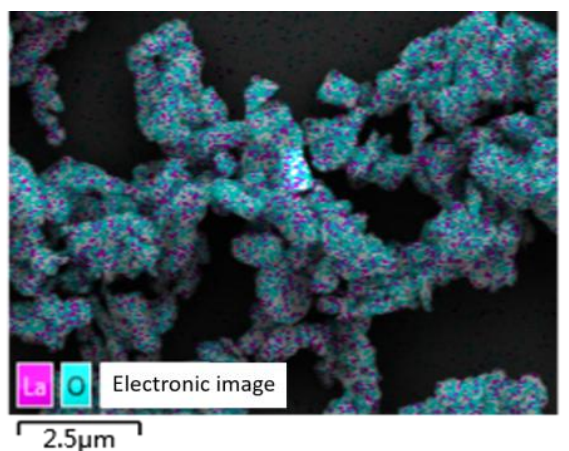

$\mathrm{O} K \alpha 1$

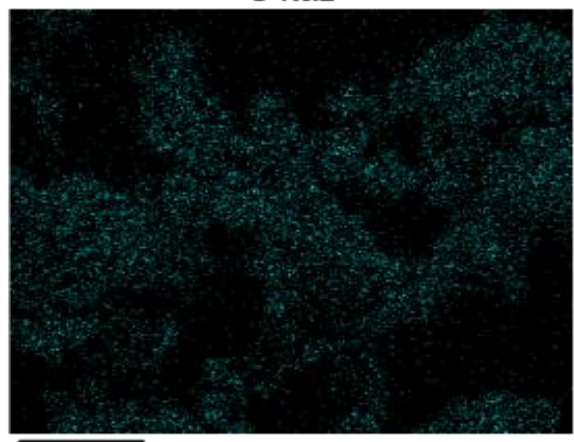

$2.5 \mu \mathrm{m}$

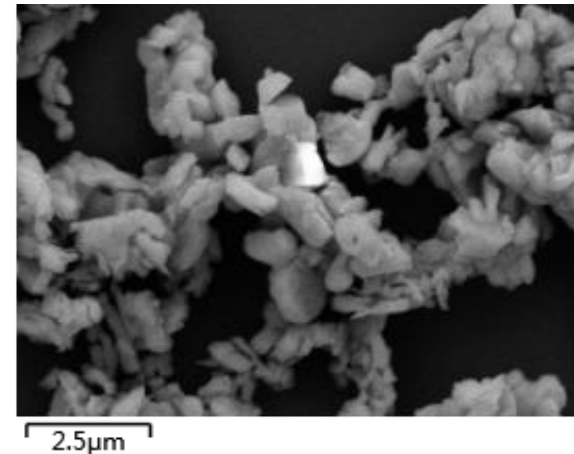

La L $\alpha 1$

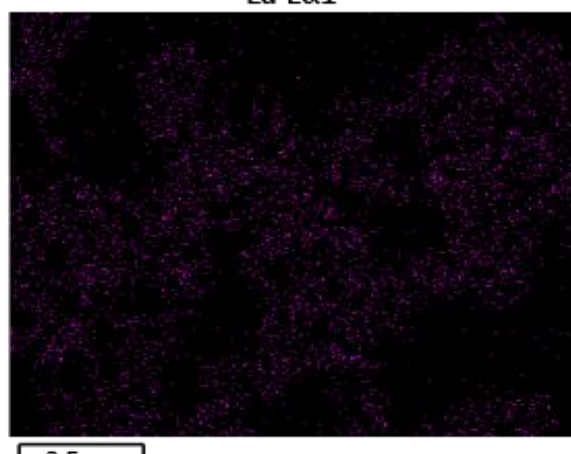

$2.5 \mu \mathrm{m}$

Figure 2. Energy dispersive spectrometry (EDS) elemental mapping images of selected $\mathrm{La}_{2} \mathrm{O}_{3}$.

Table 2. Details of the ceramic fibers used in brake composites.

\begin{tabular}{cccccc}
\hline $\begin{array}{c}\text { Property } \\
\text { Details }\end{array}$ & $\begin{array}{c}\text { Fiber Length } \\
(\mathbf{m m})\end{array}$ & $\begin{array}{c}\text { Fiber Diameter } \\
(\boldsymbol{\mu m})\end{array}$ & $\begin{array}{c}\text { Mohs } \\
\text { Hardness }\end{array}$ & $\begin{array}{c}\text { Refractoriness } \\
\left({ }^{\circ} \mathrm{C}\right)\end{array}$ & $\begin{array}{c}\text { Main Chemical } \\
\text { Components }(\%)\end{array}$ \\
\hline Specifications & $1.0-3.5$ & $2.0-4.0$ & $5-6$ & $>1170$ & $\begin{array}{c}\mathrm{SiO}_{2}: 45-55 \\
\mathrm{Al}_{2} \mathrm{O}_{3}: 40-50\end{array}$ \\
\hline
\end{tabular}

Table 3. Specifications of the resin used in brake composites.

\begin{tabular}{|c|c|c|c|c|c|c|}
\hline $\begin{array}{c}\text { Sieve Analysis } \\
\text { Test 160-mesh } \\
\text { Sieve }(\%)\end{array}$ & $\begin{array}{c}\text { Curing } \\
\text { Time } 150{ }^{\circ} \mathrm{C} \\
\text { (s) }\end{array}$ & $\begin{array}{l}\text { Flow Distance } \\
125^{\circ} \mathrm{C}(\mathrm{mm})\end{array}$ & $\begin{array}{l}\text { Viscosity } \\
\text { (mPa·s) }\end{array}$ & $\begin{array}{l}\text { Relative } \\
\text { Molecular } \\
\text { Mass }\end{array}$ & $\mathrm{pH}$ & $\begin{array}{l}\text { Free } \\
\text { Phenol } \\
(\%)\end{array}$ \\
\hline$\leq 5$ & 50-100 & $40-80$ & $3-4$ & $600-700$ & $>7$ & $\leq 5$ \\
\hline
\end{tabular}


Table 4. Details of $\mathrm{Cu}$ used in brake composites.

\begin{tabular}{ccccc}
\hline Property Details & $\begin{array}{c}\text { Purity } \\
(\mathbf{\%})\end{array}$ & $\begin{array}{c}\text { Granularity } \\
(\mathbf{m}) \text { ( })\end{array}$ & $\begin{array}{c}\text { Melting Point } \\
\left({ }^{\circ} \mathbf{C}\right)\end{array}$ & $\begin{array}{c}\text { Density } \\
\left(\mathbf{g} \cdot \mathbf{c m}^{-3}\right)\end{array}$ \\
\hline Specifications & 99.5 & 200 & 1083.4 & 8.96 \\
\hline
\end{tabular}

Brake composites containing eight ingredients were formed by keeping $85 \mathrm{wt} \%$ fixed (comprising fibres, additives and various fillers) as a parent composition. The balance $15 \mathrm{wt} \%$ was adjusted by varying the wt $\%$ of $\mathrm{Cu}$ as $15,10,5$ and $0 \mathrm{wt} \%$ and compensated with $\mathrm{La}_{2} \mathrm{O}_{3}$ (the replacement of $\mathrm{Cu}$ ). The prepared composites were designated as $\mathrm{C}_{15} \mathrm{~L}_{0}, \mathrm{C}_{10} \mathrm{~L}_{5}, \mathrm{C}_{5} \mathrm{~L}_{10}$ and $\mathrm{C}_{0} \mathrm{~L}_{15}$. The full design of the series is shown in Table 5 .

Table 5. Formulation design and designations of composites.

\begin{tabular}{cccc}
\hline Ingredients/Designation & $\begin{array}{c}\mathbf{C u} \\
(\mathbf{w t} \%)\end{array}$ & $\begin{array}{c}\mathbf{L a}_{2} \mathbf{O}_{3} \\
(\mathbf{w t} \%)\end{array}$ & $\begin{array}{c}\text { Parent Composition }{ }^{\mathbf{1}} \\
\text { (wt \%) }\end{array}$ \\
\hline $\mathrm{C}_{15} \mathrm{~L}_{0}$ & 15 & 0 & \\
$\mathrm{C}_{10} \mathrm{~L}_{5}$ & 10 & 5 & 85 \\
$\mathrm{C}_{5} \mathrm{~L}_{10}$ & 5 & 10 & \\
$\mathrm{C}_{0} \mathrm{~L}_{15}$ & 0 & 15 & \\
\hline
\end{tabular}

${ }^{1}$ Binder (phenolic resin)-20 wt \%; fibres (ceramic)-15 wt \%; additives (graphite)-3 wt \% and fillers (alumina, barite, NBR powder) -47 wt $\%$.

\subsection{Fabrication of Composites}

The ingredients were mixed in a plough type shear mixer (Model JF810S, Jilin Electrical and Mechanical Equipment Co., Ltd., Changchun, China) to ensure macroscopic homogeneity. The mixing was performed for $15 \mathrm{~min}$. Then, the mixture was placed in a four-column hydraulic machine (Model Y32-63, Ruian Huada Machinery Co., Ltd., Ruian, China). The mold cavity was filled with approximately $60 \mathrm{~g}$ of the mixture and heat-cured in a compression molding machine under a pressure of $10 \mathrm{MPa}$ for $10 \mathrm{~min}$, at a curing temperature of $160^{\circ} \mathrm{C}$. Five intermittent breathings were provided to allow the volatiles to be expelled during the initiation of curing. Then, the brake composites were post-cured in an oven (Model JF980S, Jilin Electrical and Mechanical Equipment Co., Ltd., Changchun, China) at $160{ }^{\circ} \mathrm{C}$ for $12 \mathrm{~h}$. The post-cured brake composites were surface-grinded, polished, and used for further characterization.

\subsection{Characterization of Brake Composites}

\subsubsection{Characterization of Physical, Mechanical, and Thermo-Physical Properties}

The developed brake composites were characterized for physical (density and porosity), mechanical (hardness and impact strength) and thermo-physical (thermal conductivity and thermal resistance) properties. The density of the brake composites was calculated based on Archimedes principle. The porosity was measured using the Japanese Industrial standard JIS D 4418-1996 [27], and the porosity, $p$, can be expressed as

$$
p=\frac{m_{1}-m_{0}}{\rho} \frac{1}{V} \times 100 \%
$$

where $m_{0}$ is the initial mass of the sample, $m_{1}$ is the mass of the sample after oil absorption, $\rho$ is the density of the sample, and $V$ is the volume of the sample. The hardness was measured using an electric plastic Rockwell hardness tester (Model XHRD-150, Laizhou Huayi Test Instrument Co., Ltd., Laizhou, China), according to the ISO 2039-2:1987 standard [28]. The impact strength of the brake composites was measured using a simply-supported beam pendulum impact tester (Model XJJ-5, 
Jinan Fangyuan Test Instrument Co., Ltd., Jinan, China), according to the ISO 179-1:2010 standard [29]. The impact strength, $\alpha_{\mathrm{k}}$, can be calculated by

$$
\alpha_{\mathrm{k}}=\frac{A}{b \cdot d} \times 10^{3}
$$

where $A$ is the energy required for breaking the sample, $b$ is the width of the sample, and $d$ is the thickness of the sample. The tensile strength and elastic modulus of the composites were measured using a microcomputer-controlled electronic universal testing machine (Model CMT-5105, New Sice Materials Testing Co., Ltd., Shenzhen, China), according to the ISO 527-4 standard [30]. Thermo-physical properties such as thermal conductivity and thermal resistance of the brake composites were measured using a thermal conductivity tester (Model DRL-II, Xiangtan Xiangyi Instrument Co., Ltd., Xiangtan, China), according to the ASTM D5470-2006 standard [31]. Each case was measured five times, after which the results were averaged.

\subsubsection{Tribological Characterization}

The friction and wear performance of the developed brake composites was evaluated using a chase friction tester (Model XYC-A, Xianyang Xinyi Friction and Sealing Equipment Co., Ltd., Xianyang, China), according to the standard SAE J661-1997 [32]. The test specimen had dimensions of $25.4 \mathrm{~mm} \times 25.4 \mathrm{~mm}$ and a flat bottom; the radius of the working surface is conformed to the radius of the test drum. For post-cured brake linings, we removed 1.0/1.2 $\mathrm{mm}$ to ensure that the resin-impregnated surface was totally removed. The specimen thickness should be approximately six $\mathrm{mm}$ as measured in the center of the specimen. The standard consists of two baseline tests, two fade tests, two recovery tests and a single wear test with the load of $667 \mathrm{~N}$. The interface computer stores the acquired data and displays the test results inline. The abstract of the testing schedule is shown in Table 6.

Table 6. Chase testing schedule.

\begin{tabular}{cccccccc}
\hline S. no. & Test Runs & $\begin{array}{c}\text { Speed } \\
(\mathbf{r p m})\end{array}$ & $\begin{array}{c}\text { Load } \\
\mathbf{( N )}\end{array}$ & $\begin{array}{c}\text { On Time } \\
\text { (s) }\end{array}$ & $\begin{array}{c}\text { Off Time } \\
(\mathbf{s})\end{array}$ & Repetitions & $\begin{array}{c}\text { Temperature Range } \\
\left({ }^{\circ} \mathbf{C}\right)\end{array}$ \\
\hline 1 & First Baseline & 417 & 667 & 10 & 20 & 20 & $82-93$ \\
2 & First fade & 417 & 667 & 600 & 0 & 1 & $82-288$ \\
3 & First recovery & 417 & 667 & 10 & 0 & 1 & $260-93$ \\
4 & Wear & 417 & 667 & 20 & 10 & 100 & $193-216$ \\
5 & Second fade & 417 & 667 & 600 & 0 & 1 & $93-343$ \\
6 & Second recovery & 417 & 667 & 10 & 0 & 1 & $316-93$ \\
7 & Second Baseline & 417 & 667 & 10 & 20 & 20 & $82-93$ \\
\hline
\end{tabular}

\subsubsection{Morphological Characterization}

The worn morphology of the samples after tribology testing was analyzed by SEM (Model SUPRA 55, Carl Zeiss AG, Jena, Germany) and EDS (Model X-Max50, Oxford Instruments Co., Ltd., Oxford, UK), which was used to determine the elements distribution of the worn surface of samples. All samples were coated with a thin layer of gold using a sputtering coater (Model 108, Cressington Scientific Instruments Co., Ltd., Watford, UK).

The surface roughness of the samples after tribology testing was measured by a white light confocal 3D profiler (Model Micromeasure II, Stil Co., Saint Hilaire, France). The measuring range of the area is $3000 \mu \mathrm{m} \times 3000 \mu \mathrm{m}$, and the step-length of the $X$ and $Y$ axis are both $0.5 \mu \mathrm{m}$. Each case was measured three times, after which the results were averaged.

In order to study the properties of the transfer film formed on the counter surface, the tribology tests were carried out by a microcomputer controlled friction test machine (Model MMS-2A, Jinan Yihua Tribology Testing Technology Co., Ltd., Jinan, China). The material of the counter surface is gray iron. The worn morphology of the counterpart after tribological testing was analyzed by SEM 
(Model S-3400N, Hitachi Co., Ltd., Tokyo, Japan) and EDS (Model QUANTAX, Bruker Nano GmbH, Berlin, Germany), which was used to determine the element distribution of the counter surface.

\subsubsection{X-ray Diffraction Analysis}

To study the role of $\mathrm{La}_{2} \mathrm{O}_{3}$ in polymeric matrix brake composites during the friction process, the X-ray diffractometer (Model X'pert3 and Empyrean, Panalytical B.V., Almelo, The Netherlands) was used to make a qualitative analysis on the composites. The anode material was $\mathrm{Cu}$. Measurements were obtained with a scanning rate of $0.013^{\circ} / \mathrm{s}$ and a diffraction angle range increases from $5^{\circ}$ to $90^{\circ}$ (2-Theta range), where theta is the angle of incidence of the $\mathrm{X}$-ray beam on the sample. The diffraction patterns were analyzed using MDI jade software.

\section{Results and Discussions}

\subsection{Physical, Mechanical, and Thermo-Physical Properties}

The data in Table 7 show that the density and porosity of the brake composites decrease with the decrease in $\mathrm{Cu}$ content and increase in $\mathrm{La}_{2} \mathrm{O}_{3}$ content. $\mathrm{La}_{2} \mathrm{O}_{3}$ is less dense than $\mathrm{Cu}$. With the decrease in $\mathrm{Cu}$ content, the amount of $\mathrm{La}_{2} \mathrm{O}_{3}$ increases and causes the decrease in density. The porosity of the brake composites decreases in the series because of the closer packing of notably fine $\mathrm{La}_{2} \mathrm{O}_{3}$ powder. The hardness and impact strength of the brake composites increase with the decrease in $\mathrm{Cu}$ content and increase in $\mathrm{La}_{2} \mathrm{O}_{3}$ content. $\mathrm{Cu}$ is softer than $\mathrm{La}_{2} \mathrm{O}_{3}$. With the decrease in $\mathrm{Cu}$ content, the amount of $\mathrm{La}_{2} \mathrm{O}_{3}$ increases and causes the increase in hardness. As mentioned, rare earth oxides can be used in composite materials to improve the mechanical properties $[21,22,25,26]$. The impact strength, tensile strength, and elastic modulus of the brake composites are increased because of the $\mathrm{La}_{2} \mathrm{O}_{3}$ content as expected, and the results are in accordance with our previous work $[25,26]$. The thermal performance of the composites occurs in the following order: $\mathrm{C}_{10} \mathrm{~L}_{5}>\mathrm{C}_{5} \mathrm{~L}_{10}>\mathrm{C}_{15} \mathrm{~L}_{0}>\mathrm{C}_{0} \mathrm{~L}_{15}$. Composites that contain both $\mathrm{Cu}$ and $\mathrm{La}_{2} \mathrm{O}_{3}$ are better than those containing only $\mathrm{Cu}$ or $\mathrm{La}_{2} \mathrm{O}_{3}$ in this aspect. We expect that $\mathrm{La}_{2} \mathrm{O}_{3}$ has synergistic effects with $\mathrm{Cu}$ in composites, which can further improve the thermal performance of the brake composites.

Table 7. Properties of the developed composites.

\begin{tabular}{|c|c|c|c|c|c|c|c|c|}
\hline \multirow{2}{*}{ Properties } & \multicolumn{2}{|c|}{$\mathrm{C}_{15} \mathrm{~L}_{0}$} & \multicolumn{2}{|c|}{$\mathrm{C}_{10} \mathrm{~L}_{5}$} & \multicolumn{2}{|c|}{$\mathrm{C}_{5} \mathrm{~L}_{10}$} & \multicolumn{2}{|c|}{$\mathrm{C}_{0} \mathrm{~L}_{15}$} \\
\hline & Average & $\begin{array}{l}\text { Standard } \\
\text { Deviation }\end{array}$ & Average & $\begin{array}{l}\text { Standard } \\
\text { Deviation }\end{array}$ & Average & $\begin{array}{l}\text { Standard } \\
\text { Deviation }\end{array}$ & Average & $\begin{array}{l}\text { Standard } \\
\text { Deviation }\end{array}$ \\
\hline Density $\left(\mathrm{g} \cdot \mathrm{cm}^{-3}\right)$ & 2.24 & 0.01 & 2.22 & 0.02 & 2.15 & 0.03 & 2.09 & 0.02 \\
\hline Porosity (\%) & 0.57 & 0.03 & 0.51 & 0.04 & 0.42 & 0.02 & 0.40 & 0.01 \\
\hline Hardness (HRM) & 103.2 & 0.6 & 109.1 & 0.5 & 111.9 & 1.0 & 112.9 & 0.4 \\
\hline $\begin{array}{l}\text { Impact strength } \\
\left(\mathrm{kJ} / \mathrm{m}^{2}\right)\end{array}$ & 7.13 & 0.23 & 7.54 & 0.09 & 8.13 & 0.34 & 9.90 & 0.20 \\
\hline Tensile strength $(\mathrm{MPa})$ & 37.94 & 0.51 & 38.96 & 0.57 & 39.20 & 0.39 & 41.24 & 0.43 \\
\hline Elastic modulus (Gpa) & 1.30 & 0.04 & 1.37 & 0.03 & 1.43 & 0.06 & 1.58 & 0.07 \\
\hline $\begin{array}{l}\text { Thermal conductivity } \\
\qquad(\mathrm{W} / \mathrm{m} \cdot \mathrm{K})\end{array}$ & 1.83 & 0.04 & 1.95 & 0.05 & 1.88 & 0.02 & 1.79 & 0.03 \\
\hline $\begin{array}{l}\text { Thermal resistance } \\
\left(\times 10^{-4} \mathrm{~K} \cdot \mathrm{m}^{2} / \mathrm{W}\right)\end{array}$ & 16.70 & 0.37 & 15.40 & 0.41 & 16.04 & 0.17 & 17.30 & 0.29 \\
\hline
\end{tabular}

\subsection{Tribological Properties}

\subsubsection{Friction Coefficient}

The variation in friction coefficient $(\mu)$ with the decrease in $\mathrm{Cu}$ content and increase in $\mathrm{La}_{2} \mathrm{O}_{3}$ content is shown in Figure 3. The normal friction coefficient $\left(\mu_{\text {normal }}\right)$ was calculated as the average of selected $\mu$ values corresponding to $93,121,149$, and $204{ }^{\circ} \mathrm{C}$ from the second fade cycle. For an ideal automotive brake composites, $\mu$ should be $0.20-0.70$ (higher value is better). The hot friction coefficient ( $\mu_{\text {hot }}$ ) was calculated as the average of selected $\mu$ values that correspond to 204 and $149^{\circ} \mathrm{C}$ of the first recovery cycle, $232,260,288,316$, and $343^{\circ} \mathrm{C}$ of the second fade cycle, and 260,204 and $149{ }^{\circ} \mathrm{C}$ of the 
second recovery cycle. $\Delta \mu$ was defined as the difference between $\mu_{\text {normal }}$ and $\mu_{\text {hot }}$ to characterize the friction coefficient stability and is shown in Figure $3 b$.

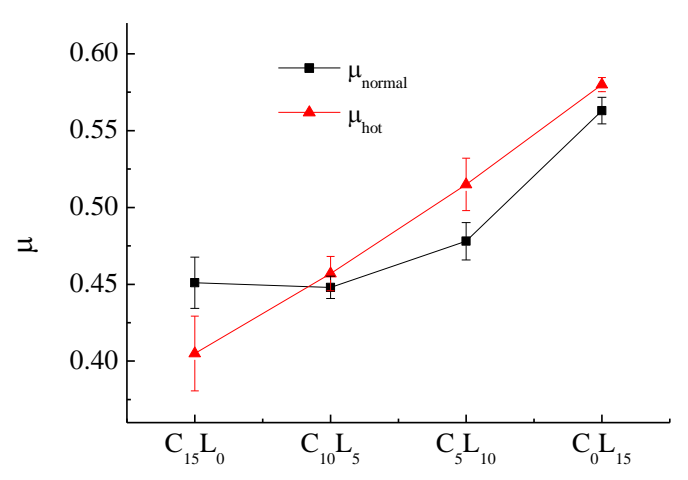

(a)

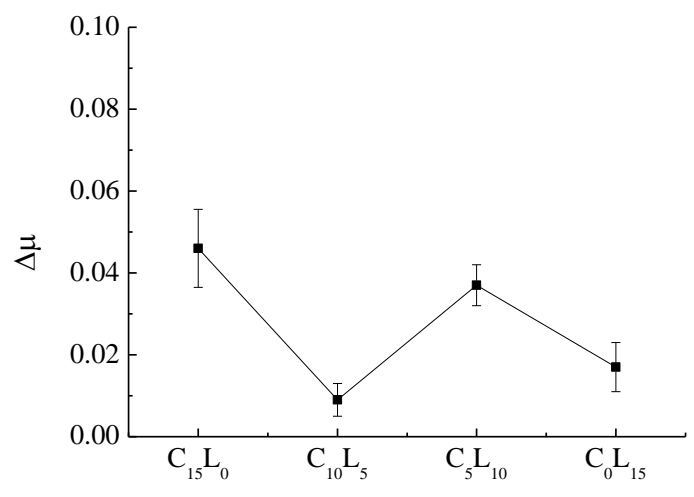

(b)

Figure 3. Variation in $\mu_{\text {normal}}, \mu_{\text {hot }}$ and $\Delta \mu$ ( $\mu$ fluctuations) with different wt $\%$ of $\mathrm{Cu}$ and $\mathrm{La}_{2} \mathrm{O}_{3}$ for brake composites: (a) $\mu_{\text {normal }}$ and $\mu_{\text {hot }}$; (b) $\Delta \mu$.

Figure 3a shows that $\mu_{\text {normal }}$ and $\mu_{\text {hot }}$ increase with the decrease in $\mathrm{Cu}$ content and increase in $\mathrm{La}_{2} \mathrm{O}_{3}$ content, particularly the increase in $\mu_{\text {hot }}$. Except for $\mathrm{C}_{15} \mathrm{~L}_{0}, \mu_{\text {hot }}$ was higher than $\mu_{\text {normal }}$ for all composites, which shows the good heating fade resistance of the developed brake composites containing $\mathrm{La}_{2} \mathrm{O}_{3}$. Thus, the addition of $\mathrm{La}_{2} \mathrm{O}_{3}$ effectively improves $\mu$, particularly for the improvement of $\mu_{\text {hot }}$. In Figure $3 b$, the $\mathrm{La}_{2} \mathrm{O}_{3}$-containing brake composites has lower $\Delta \mu$ than the $\mathrm{La}_{2} \mathrm{O}_{3}$-free brake composites. $\mathrm{C}_{10} \mathrm{~L}_{5}$ has the lowest $\Delta \mu$, followed by $\mathrm{C}_{0} \mathrm{~L}_{15}$ and $\mathrm{C}_{5} \mathrm{~L}_{10}$. However, $\mathrm{C}_{15} \mathrm{~L}_{0}$ has the highest $\Delta \mu$, which is not the desired feature. Thus, the addition of $\mathrm{La}_{2} \mathrm{O}_{3}$ is more conducive to the stability of the friction coefficient for brake composites than $\mathrm{Cu}$. $\mathrm{C}_{0} \mathrm{~L}_{15}$ has the best friction properties. According to modern tribological theory, sliding friction coefficient, $\mu$, is mainly composed of three kinds of friction coefficients, including $\mu_{\mathrm{a}}$ caused by adhesion, $\mu_{\mathrm{f}}$ caused by furrow action and $\mu_{\mathrm{r}}$ caused by roughness. The sliding friction coefficient, $\mu$, can be given by

$$
\mu=\mu_{\mathrm{a}}+\mu_{\mathrm{f}}+\mu_{\mathrm{r}}
$$

where $\mu_{\mathrm{r}}$ is not related to the composition of the material but is affected by the state of the friction surface. The above results from Table 7 proved that the hardness, tensile strength, and elastic modulus of the brake composites increase with the decrease in $\mathrm{Cu}$ content and increase in $\mathrm{La}_{2} \mathrm{O}_{3}$ content. With the increase in tensile strength and elastic modulus of the composites, the shear-resistant of the composite surface is strengthened, leading to the improvement in friction coefficient, which is caused by adhesion $\left(\mu_{\mathrm{a}}\right)$. With the increase in the hardness of the composites, the furrow action between the surface of the micro-convex body and its counterpart is strengthened, leading to an improvement in the friction coefficient, which is caused by the furrow action $\left(\mu_{\mathrm{f}}\right)$. Therefore, the sliding friction coefficient increases with the increase in $\mathrm{La}_{2} \mathrm{O}_{3}$ content.

\subsubsection{Fade and Recovery Behavior}

To characterize the fade and recovery properties of all selected composites, various derived friction performance parameters such as $\mu_{\text {fade }}$, fade $\%$ and recovery $\%$ were defined as follows: $\mu_{\text {fade }}$ : average $\mu$ of the fade and recovery cycles above $260{ }^{\circ} \mathrm{C}$. A higher $\mu$ indicates a better heat fading resistance. $\mu_{\text {baseline: }}$ average $\mu$ of the first baseline cycle. $\mu_{\text {baseline }}$ is defined to assess the friction performance without the effect of temperature. fade $\%: \mu_{\text {fade }} / \mu_{\text {baseline }} \times 100$. A higher $\%$ fade ratio is desirable. For an ideal brake composites, fade $\%$ should be greater than $80 \%$. recovery $\%: \mu_{\text {recovery }} / \mu_{\text {baseline }} \times 100$. A higher recovery $\%$ is desirable. 
In general, for an acceptable brake composites, recovery $\%$ should be in the desired range $(80 \%-100 \%)$. Figure 4 shows the fade and recovery behaviors of all selected composites.

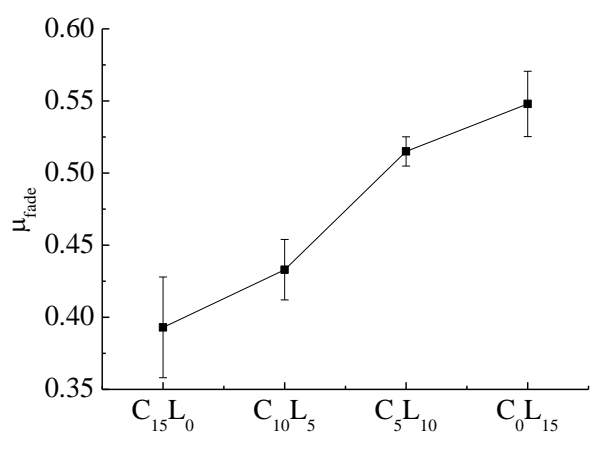

(a)

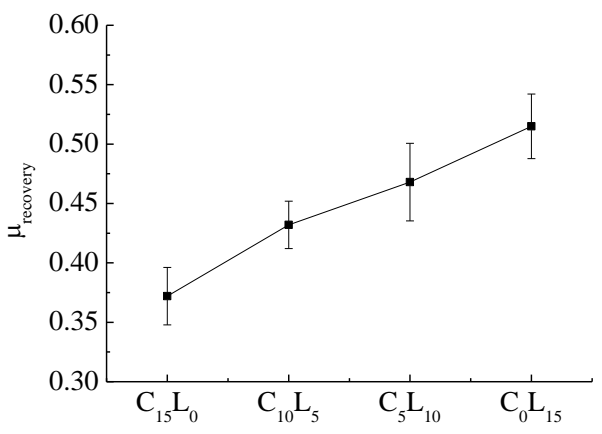

(c)

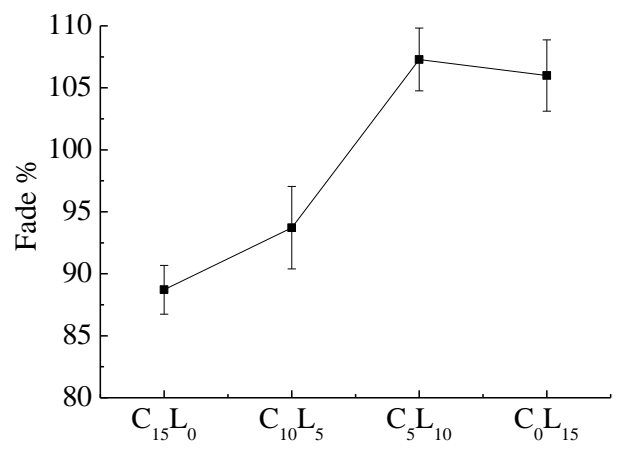

(b)

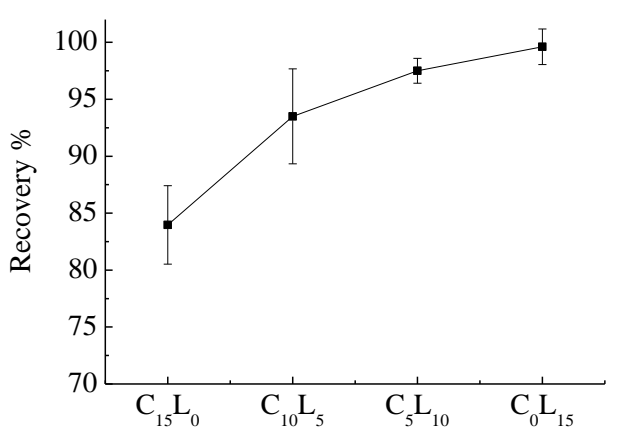

(d)

Figure 4. Fade and recovery behaviors of the brake composites: (a) $\mu_{\text {fade }}$; (b) fade $\%$; (c) $\mu_{\text {recovery; }}$; (d) recovery\%.

Figure $4 \mathrm{a}, \mathrm{b}$ shows that $\mu_{\text {fade }}$ and fade $\%$ almost increase with the decrease in $\mathrm{Cu}$ content and increase in $\mathrm{La}_{2} \mathrm{O}_{3}$ content. The added $\mathrm{La}_{2} \mathrm{O}_{3}$ into brake composites has the benefit of improving the heat resistance function. The fade $\%$ of $\mathrm{C}_{5} \mathrm{~L}_{10}$ and $\mathrm{C}_{0} \mathrm{~L}_{15}$, whose values are greater than 100 , show that $\mu$ of the composites dose not decrease with the increase in temperature but increases and proves the good heating fade resistance of the developed brake composites. This tribological property is different from the traditional properties of the brake composites and similar to carbon-carbon composites, which have been widely used in aircraft brake composites because of their excellent tribological properties [33]. It is expected that the addition of $\mathrm{La}_{2} \mathrm{O}_{3}$ in polymeric matrix brake composites will significantly improve the tribological properties. Figure $4 \mathrm{c}$, $\mathrm{d}$ shows that $\mu_{\text {recovery }}$ and recovery $\%$ increase with the decrease in $\mathrm{Cu}$ content and increase in $\mathrm{La}_{2} \mathrm{O}_{3}$ content. The added $\mathrm{La}_{2} \mathrm{O}_{3}$ into brake composites has the benefit of improving the recovery function. Compared with $\mathrm{C}_{10} \mathrm{~L}_{5}$ (composites containing only $\mathrm{Cu}$ ), $\mathrm{C}_{10} \mathrm{~L}_{5}$ (composites containing only $\mathrm{La}_{2} \mathrm{O}_{3}$ ) show better heat fading resistance and recovery performance. It can be seen that $\mathrm{La}_{2} \mathrm{O}_{3}$ is more conducive to improving the heat fading resistance and recovery performance of the brake composites than copper.

\subsubsection{Wear Behavior}

The wear of the brake composites was measured by the weight loss method after completing various baseline, fade, and recovery cycles. From Figure 5, the weight loss of the composites first decreases and then increases with the decrease in $\mathrm{Cu}$ content and increase in $\mathrm{La}_{2} \mathrm{O}_{3}$ content. $\mathrm{C}_{10} \mathrm{~L}_{5}$ shows the highest wear resistance, followed by $\mathrm{C}_{5} \mathrm{~L}_{10}$. The composite $\mathrm{C}_{15} \mathrm{~L}_{0}$ is moderate, whereas $\mathrm{C}_{0} \mathrm{~L}_{15}$ is poor in wear performance. Evans and Marshall [34] studied the theory of wear and concluded 
that the wear loss was directly proportional to the elastic modulus and inversely proportional to the hardness. As mentioned above, with the decrease in $\mathrm{Cu}$ content, the amount of $\mathrm{La}_{2} \mathrm{O}_{3}$ increases and causes the increase in hardness and elastic modulus. From Table 7, it can be seen that the hardness firstly increases rapidly at the beginning and then increases slowly with the increase in $\mathrm{La}_{2} \mathrm{O}_{3}$ content, while the elastic modulus increases slowly the first time and then rapidly later. Thus, the wear loss of the composites firstly decreases due to the rapid increase in hardness, and then increases due to the accelerative increase in the elastic modulus. From Figure 5, it also can be seen that the composites that contain both $\mathrm{Cu}$ and $\mathrm{La}_{2} \mathrm{O}_{3}$ have better wear performance than those containing only $\mathrm{Cu}$ or $\mathrm{La}_{2} \mathrm{O}_{3}$, where similar synergistic effects were observed with the effect on the thermal performance, as shown in Table 7. When the brake composites have poorer thermal conductivity, less heat is conducted away from the friction interface, contributing to the increase in thermal decomposition of the resin and wear loss of the composites.

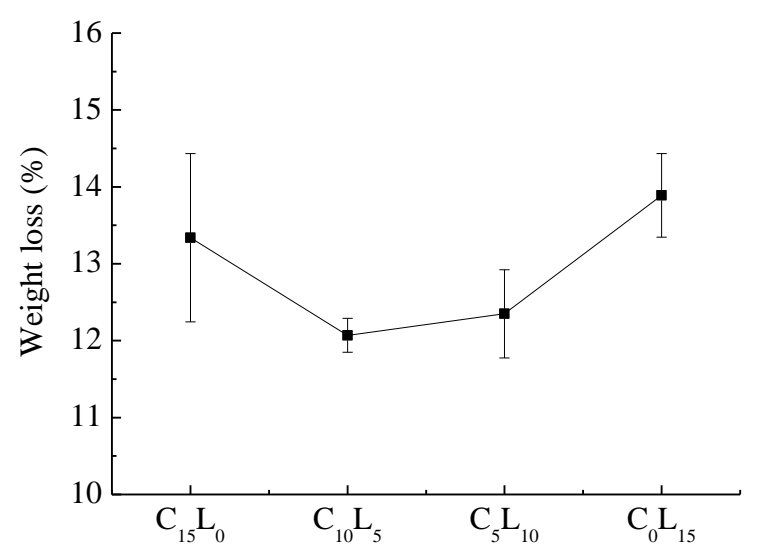

Figure 5. Wear performance of the brake composites.

Thus, overall, $\mathrm{C}_{0} \mathrm{~L}_{15}$ is superior to $\mathrm{C}_{15} \mathrm{~L}_{0}$ in most properties such as $\mu_{\text {normal }}, \mu_{\text {hot }}, \Delta \mu, \mu_{\text {fade }}$, $\mu_{\text {recovery }}$, fade $\%$ and recovery $\%$, whereas $\mathrm{C}_{0} \mathrm{~L}_{15}$ has slightly superior wear resistance. For brake composites, friction properties are more important than wear resistance. Hence, $\mathrm{C}_{0} \mathrm{~L}_{15}$ is the optimal sample in this study for the best possible combination of performance properties.

\subsection{Worn Surface Analysis}

The wear mechanisms during wearing of friction materials are extremely complex dynamic processes, since several interactions such as physical, chemical, and mechanical are simultaneously operative. Consequently, they depend on various factors such as the basic compositions, their synergistic effect, load, velocity, interface temperature, and friction surface characteristics. It is generally acknowledged by most scholars that a uniform, continuous and thin friction film on the interface is beneficial to the stability of $\mu$ and good wear resistance [35-37]. The worn surfaces of the brake composites studied by SEM are arranged according to their increasing wear resistance $\left(\mathrm{C}_{10} \mathrm{~L}_{5}>\mathrm{C}_{5} \mathrm{~L}_{10}>\mathrm{C}_{15} \mathrm{~L}_{0}>\mathrm{C}_{0} \mathrm{~L}_{15}\right)$ in Figure 6. Figure 7 shows their EDS micrographs, and the EDS spectrums are given in Figure S1 in the Supplementary Materials. 


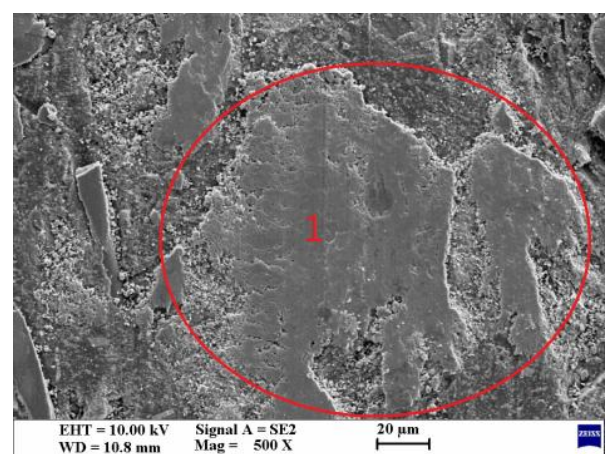

(a)

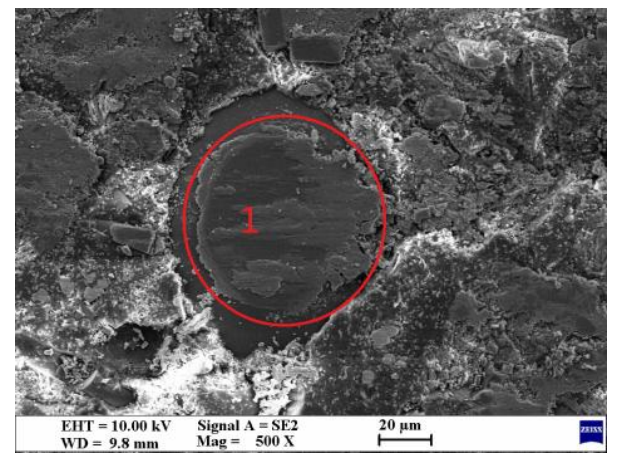

(c)

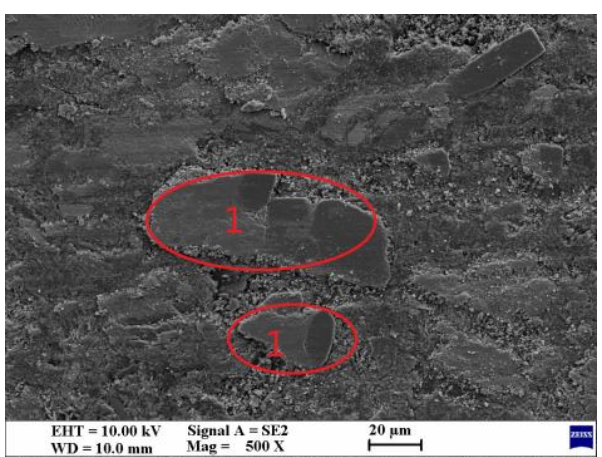

(b)

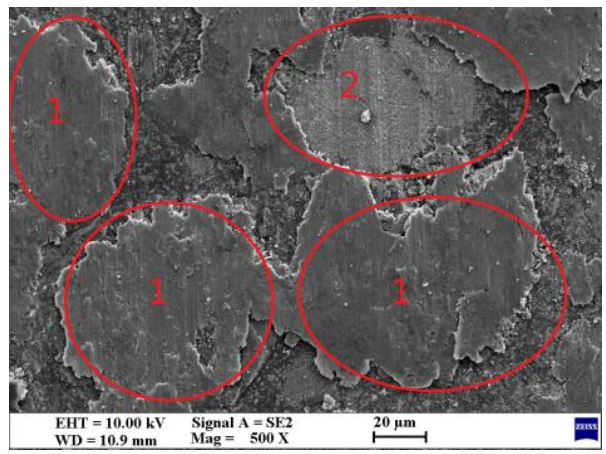

(d)

Figure 6. SEM micrographs of the worn surfaces of the brake composites: (a) $\mathrm{C}_{10} \mathrm{~L}_{5}$; (b) $\mathrm{C}_{5} \mathrm{~L}_{10}$; (c) $\mathrm{C}_{15} \mathrm{~L}_{0}$; (d) $\mathrm{C}_{0} \mathrm{~L}_{15}$.

The distinct features observed in all micrographs in Figure 6 are the thickness and continuity of the friction film (marked as 1), which are possibly enriched with $\mathrm{Cu}$ and $\mathrm{La}_{2} \mathrm{O}_{3}$ and must be further confirmed by EDS studies (Figure 7). The micrographs of $\mathrm{C}_{10} \mathrm{~L}_{5}$ (Figure 6a) show the smoothest and cleanest surface. A thinner and most continuous film enriched with $\mathrm{Cu}$ and $\mathrm{La}_{2} \mathrm{O}_{3}$ (Figure 7a) of uniform thickness was observed throughout the surface with no crack or degradation of ingredients, supporting its highest wear resistance and stable friction behavior. The surface of $\mathrm{C}_{5} \mathrm{~L}_{10}$ (Figure $6 \mathrm{~b}$ ) shows discontinuous pieces of friction film enriched with $\mathrm{Cu}$ and $\mathrm{La}_{2} \mathrm{O}_{3}$ (Figure $7 \mathrm{~b}$ ), which was responsible for its higher wear resistance. The micrographs of $\mathrm{C}_{15} \mathrm{~L}_{0}$ (Figure 6c) show some damage to the ingredients, wear debris, and the thinnest but discontinuous film enriched with $\mathrm{Cu}$ (Figure 7c), which was responsible for some wear. The surface of $\mathrm{C}_{0} \mathrm{~L}_{15}$ (Figure $6 \mathrm{~d}$ ) shows the thickest friction film enriched with $\mathrm{La}_{2} \mathrm{O}_{3}$ (Figure 7d). A small amount of thick friction film (marked as 2) was easily abraded from the surface, which caused more wear.

By contrast with the EDS elemental mapping images of the worn surface of $\mathrm{C}_{15} \mathrm{~L}_{0}$ (Figure $7 \mathrm{c}$ ) and $\mathrm{C}_{0} \mathrm{~L}_{15}$ (Figure $7 \mathrm{~d}$ ), lanthanum oxide is more uniformly distributed on the surface than copper, which is more conducive to the formation of a continuous friction film. The lanthanum oxides are allotropes of hexagonal crystals, which are similar to layered structures, possessing high melting points and a low hardness. From Figure 7d, it can be seen that the friction film enriched with La coated on the worn surface, which can act as a solid lubricant at high temperatures as expected [24]. With more $\mathrm{La}_{2} \mathrm{O}_{3}$, a thicker friction film is formed. However, the thick oxide film is more easily worn out from the surface as $\mathrm{C}_{0} \mathrm{~L}_{15}$, which is not desirable. 

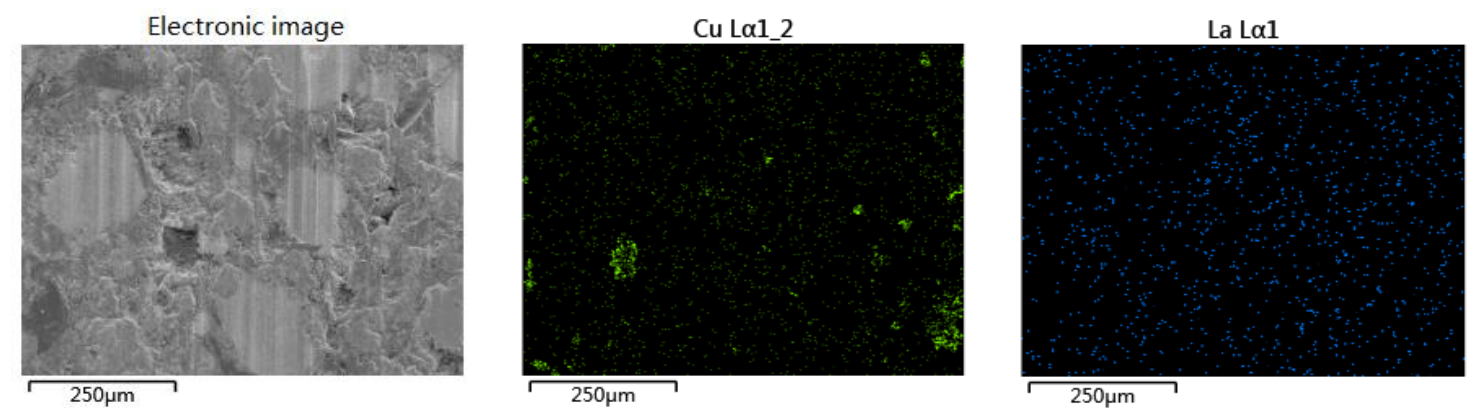

(a)
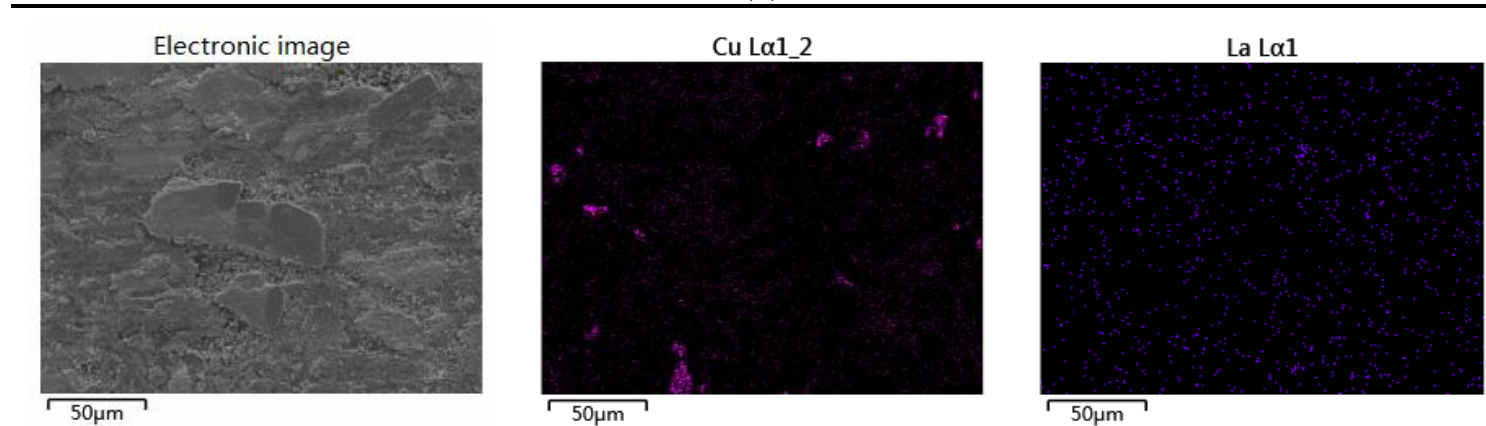

(b)
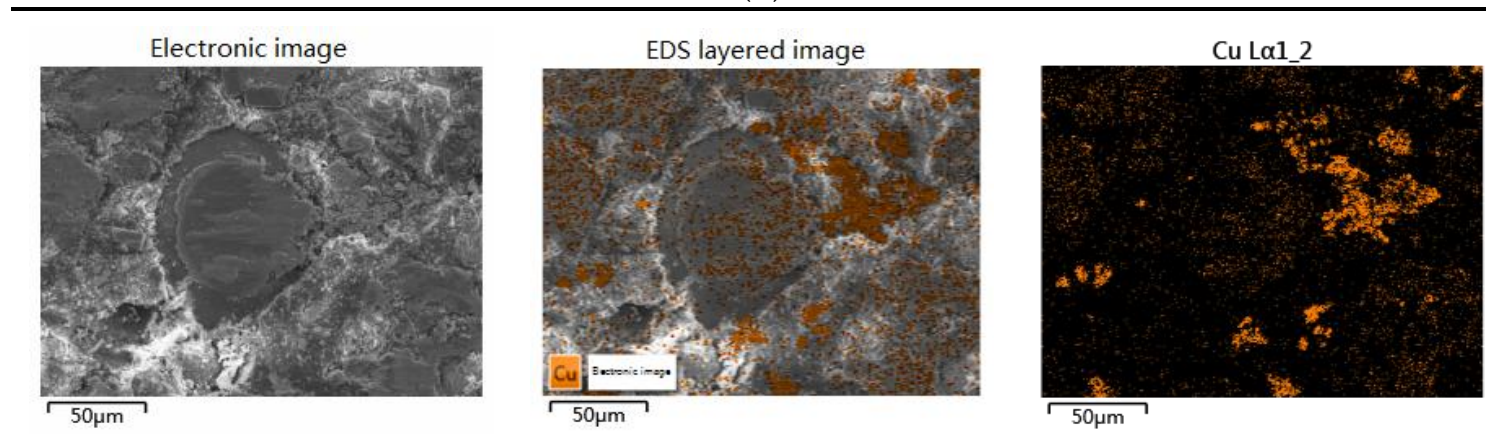

(c)
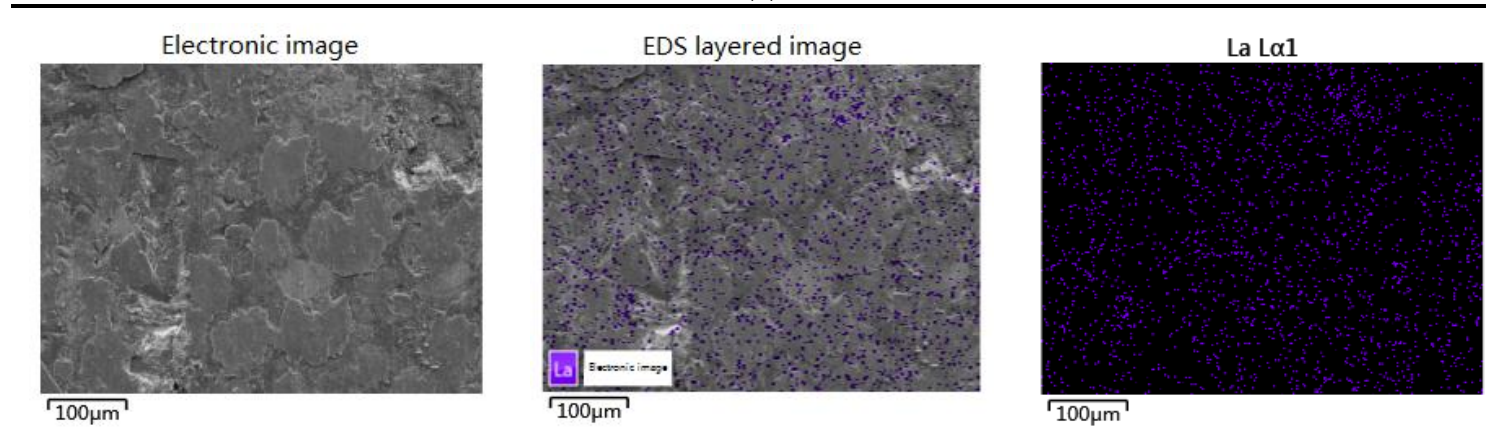

(d)

Figure 7. Worn surfaces of composites-EDS elemental mapping images: (a) $\mathrm{C}_{10} \mathrm{~L}_{5}$; (b) $\mathrm{C}_{5} \mathrm{~L}_{10}$; (c) $\mathrm{C}_{15} \mathrm{~L}_{0}$; (d) $\mathrm{C}_{0} \mathrm{~L}_{15}$.

\subsection{Three-Dimensional Surface Texture Analysis}

As previously mentioned, the friction coefficient caused by roughness, $\mu_{r}$, is affected by the state of the friction surface. The measurements of 3-D surface topography of the worn surfaces of the brake composites after tribology testing are shown in Figure 8. The obtained roughness parameters of the worn surface roughness of specimens are shown in Table 8. 


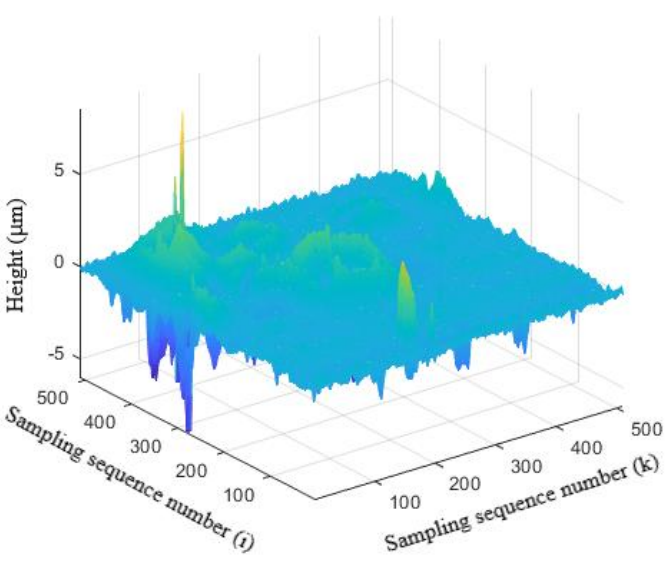

(a)

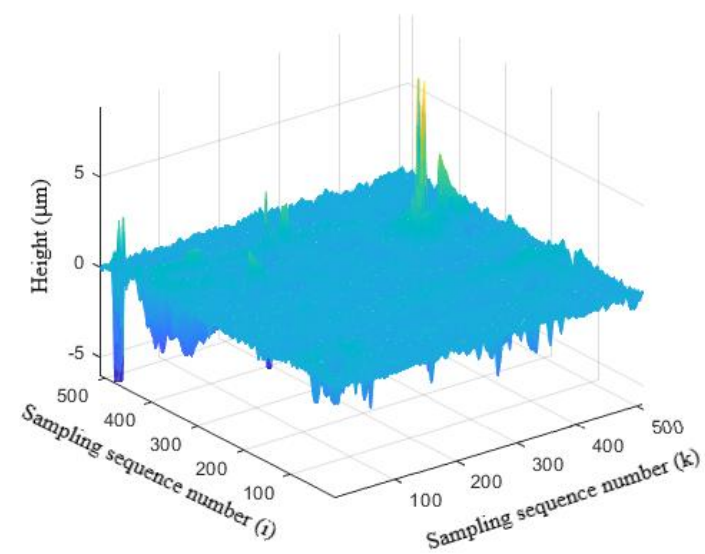

(c)

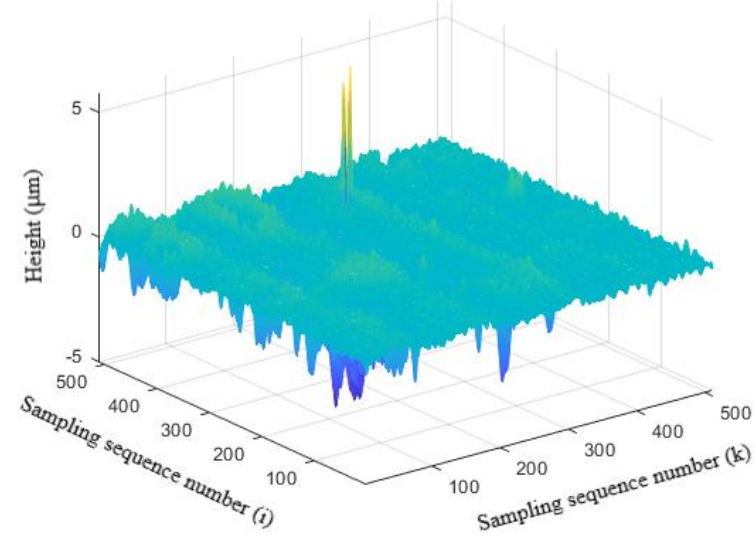

(b)

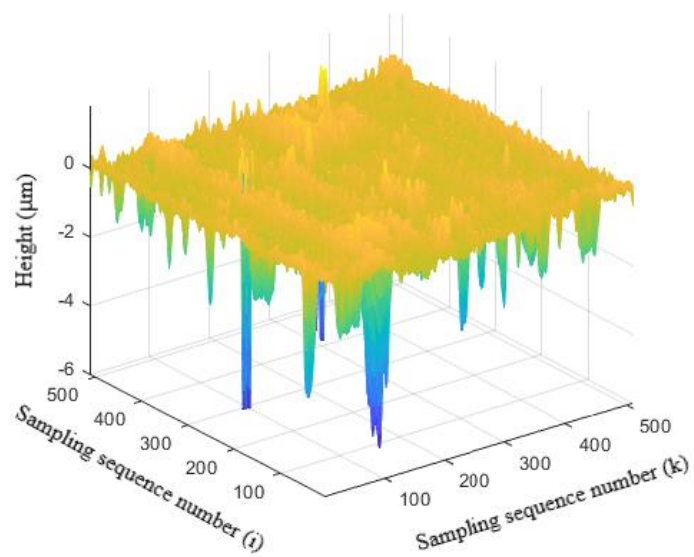

(d)

Figure 8. 3-D surface topography of the worn surfaces of the brake composites: (a) $\mathrm{C}_{15} \mathrm{~L}_{0} ;(\mathbf{b}) \mathrm{C}_{10} \mathrm{~L}_{5}$; (c) $\mathrm{C}_{5} \mathrm{~L}_{10} ;(\mathbf{d}) \mathrm{C}_{0} \mathrm{~L}_{15}$.

Table 8. Roughness parameter of the worn surface roughness of specimens.

\begin{tabular}{ccccccccc}
\hline \multirow{2}{*}{$\begin{array}{c}\text { Roughness } \\
\text { Parameters }\end{array}$} & \multicolumn{2}{c}{$\mathrm{C}_{\mathbf{1 5}} \mathbf{L}_{\mathbf{0}}$} & \multicolumn{2}{c}{$\mathrm{C}_{\mathbf{1 0}} \mathbf{L}_{\mathbf{5}}$} & \multicolumn{2}{c}{$\mathrm{C}_{\mathbf{5}} \mathbf{L}_{\mathbf{1 0}}$} & \multicolumn{2}{c}{$\mathrm{C}_{\mathbf{0}} \mathbf{L}_{\mathbf{1 5}}$} \\
\cline { 2 - 9 } & Average & $\begin{array}{c}\text { Standard } \\
\text { Deviation }\end{array}$ & Average & $\begin{array}{c}\text { Standard } \\
\text { Deviation }\end{array}$ & Average & $\begin{array}{c}\text { Standard } \\
\text { Deviation }\end{array}$ & Average & $\begin{array}{c}\text { Standard } \\
\text { Deviation }\end{array}$ \\
\hline$S_{a}(\mu \mathrm{m})$ & 0.44 & 0.02 & 0.22 & 0.01 & 0.23 & 0.01 & 0.21 & 0.01 \\
$S_{q}(\mu \mathrm{m})$ & 0.76 & 0.03 & 0.36 & 0.01 & 0.42 & 0.01 & 0.41 & 0.01 \\
$S_{k u}$ & 12.90 & 1.35 & 28.48 & 1.85 & 46.26 & 1.59 & 55.02 & 1.87 \\
\hline
\end{tabular}

$S_{a}$ shows the deviation of surface height, and can be expressed as

$$
S_{a}=\frac{1}{M N} \sum_{i=0}^{M-1} \sum_{k=0}^{N-1}\left|z\left(x_{i}, y_{k}\right)-u\right|
$$

where $z\left(x_{k}, y_{l}\right)$ is the height of the $\mathrm{Z}$ axis at the coordinate point, $M$ is the length of 3-D surface image, $N$ is the width of 3-D surface image, and $u$ can be computed by

$$
u=\frac{1}{M N} \sum_{i=0}^{M-1} \sum_{k=0}^{N-1} z\left(x_{i}, y_{k}\right)
$$


$S_{q}$ shows the standard deviation of surface height, and can be given by

$$
S_{q}=\sqrt{\frac{1}{M N} \sum_{i=0}^{M-1} \sum_{k=0}^{N-1}\left[z\left(x_{i}, y_{k}\right)-u\right]^{2}}
$$

$S_{k u}$ shows the steepness of surface topography, and can be defined as

$$
S_{k u}=\frac{1}{M N S_{q}} \sum_{i=0}^{M-1} \sum_{k=0}^{N-1}\left[z\left(x_{i}, y_{k}\right)-u\right]^{4}
$$

where $S_{k u}=3, S_{k u}<3$, and $S_{k u}>3$ are interpreted as a normal distribution, the probability dispersion of height distribution, and the probability concentration of height distribution, respectively. The smaller $\mathrm{S}_{\mathrm{ku}}$ is, the more amounts of surface peaks will be.

From Figure 8 and Table 8 , it can be seen that the value of $S_{q}$ of the brake composites containing $\mathrm{La}_{2} \mathrm{O}_{3}$ is much lower than that containing $\mathrm{Cu}$ under the same condition, indicating that the brake composites containing $\mathrm{La}_{2} \mathrm{O}_{3}$ have a lower surface roughness during the friction process. As mentioned above, $\mathrm{La}_{2} \mathrm{O}_{3}$ is more conducive to the formation of friction film than $\mathrm{Cu}$ and causes the decrease in surface roughness. The values of $S_{k u}$ in Table 8 are all greater than three, indicating that all the specimens surface have surface peaks. With the decrease in $\mathrm{Cu}$ content, the amount of $\mathrm{La}_{2} \mathrm{O}_{3}$ increases and causes the increase in the values of $S_{k u}$. It can be seen that the surface of $\mathrm{C}_{0} \mathrm{~L}_{15}$ demonstrates more peaks than any other types. As the amount of peaks increases on the surface, the furrow action enhances and causes the increase in friction coefficient. Thus, $\mathrm{C}_{0} \mathrm{~L}_{15}$ has the best friction properties.

\subsection{Friction Transfer Film}

The tribological properties of the brake composites is directly affected by the thickness, uniformity, and continuity of the transfer film formed on the counter surface. Many research results indicated that copper has a good ductility, which is conducive to the formation of stable, continuous and uniform friction transfer film on the counter surface, and plays a role in stabilizing the friction coefficient and reducing wear loss $[9-11,38]$. In order to study whether $\mathrm{La}_{2} \mathrm{O}_{3}$ could play a role similar to $\mathrm{Cu}$ during the friction process, the coupled parts before and after tribology testing with $\mathrm{C}_{15} \mathrm{~L}_{0}$ and $\mathrm{C}_{0} \mathrm{~L}_{15}$ were analyzed by SEM and EDS. The SEM micrographs and EDS spectrums of the counter surface are shown in Figure 9. From Figure 9, compared with the coupled part before tribology testing (Figure 9a), transfer films were formed on the counter surface after tribology testing (Figure 9c,e), which were further confirmed as films enriched with $\mathrm{Cu}$ and $\mathrm{La}_{2} \mathrm{O}_{3}$ (Figure $9 \mathrm{~d}, \mathrm{f}$ ), respectively. Compared with Figure $9 c$, the transfer layer formed on the counter surface after tribology testing with $\mathrm{C}_{0} \mathrm{~L}_{15}$ (Figure $9 \mathrm{e}$ ) was more continuous and compacted, helping to the better tribological properties of $\mathrm{C}_{0} \mathrm{~L}_{15}$ than $\mathrm{C}_{15} \mathrm{~L}_{0}$. It can be seen that the addition of $\mathrm{La}_{2} \mathrm{O}_{3}$ to brake composites is more conducive to the formation of uniform and continuous transfer film on the counter surface than $\mathrm{Cu}$. Overall, rare earth $\mathrm{La}_{2} \mathrm{O}_{3}$ can be successfully used as a replacement for $\mathrm{Cu}$ in brake composites. 


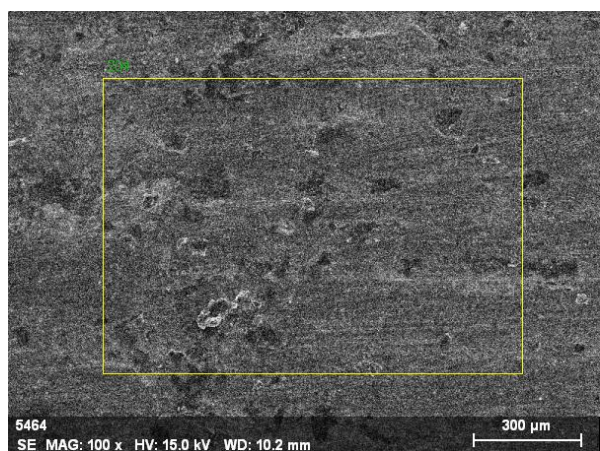

(a)

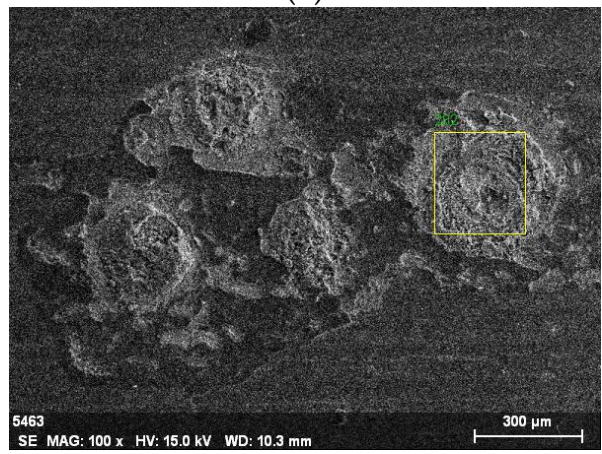

(c)

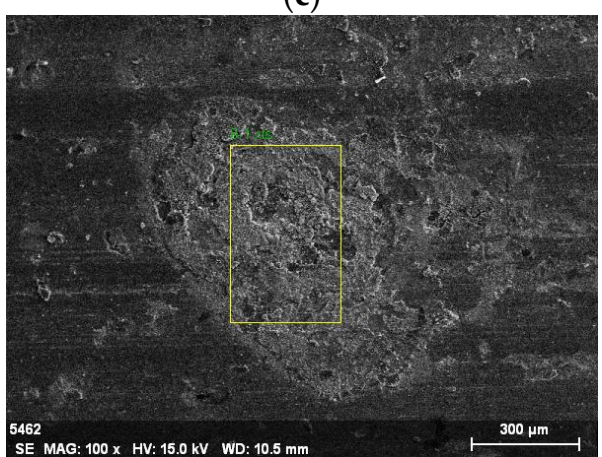

(e)

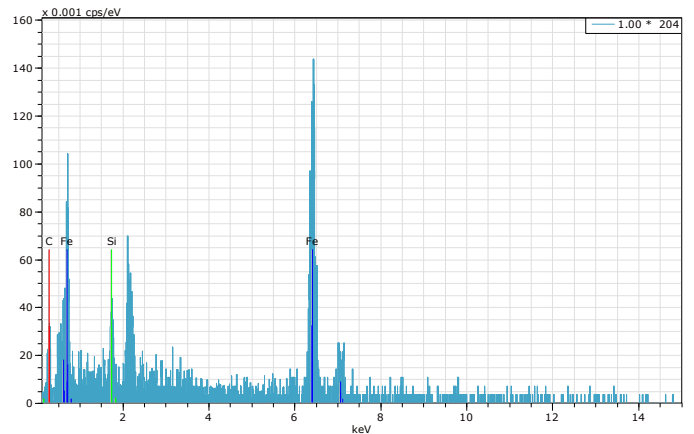

(b)

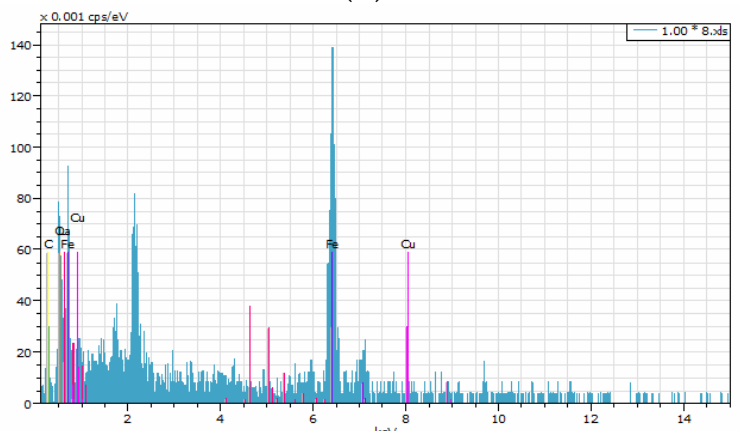

(d)

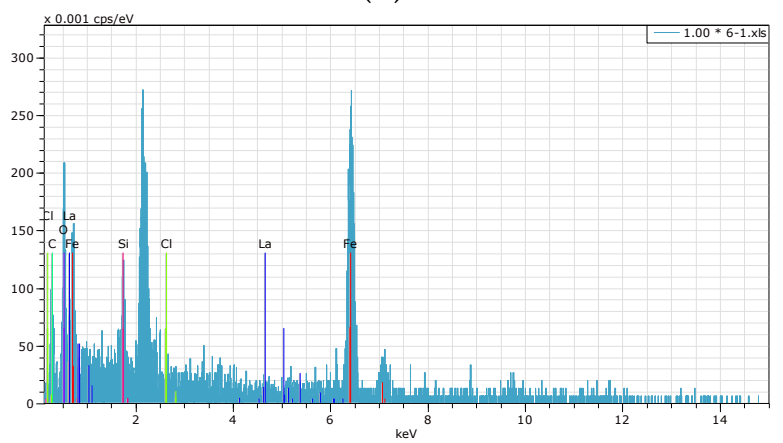

(f)

Figure 9. SEM micrographs and EDS spectrums of the counter surface: (a) SEM micrograph of the counter surface before tribology testing; (b) EDS spectrum of the counter surface before tribology testing; (c) SEM micrograph of the counter surface after tribology testing with $\mathrm{C}_{15} \mathrm{~L}_{0}$; (d) EDS spectrum of the counter surface after tribology testing with $\mathrm{C}_{15} \mathrm{~L}_{0}$; (e) SEM micrograph of the counter surface after tribology testing with $\mathrm{C}_{0} \mathrm{~L}_{15}$; (f) EDS spectrum of the counter surface after tribology testing with $\mathrm{C}_{0} \mathrm{~L}_{15}$.

\subsection{X-ray Diffraction Analysis}

To further study the role of $\mathrm{La}_{2} \mathrm{O}_{3}$ during friction and wear processes, the qualitative phase analysis of $\mathrm{C}_{0} \mathrm{~L}_{15}$ before and after tribology testing was carried out with X-ray diffraction (XRD). The XRD patterns are shown in Figure 10. It can be seen that $\mathrm{C}_{0} \mathrm{~L}_{15}$ before tribology testing appears to have diffraction peaks of $\mathrm{La}_{2} \mathrm{O}_{3}, \mathrm{Al}_{2} \mathrm{O}_{3}, \mathrm{SiO}_{2}$ and $\mathrm{BaSO}_{4}$, which are consistent with the composition of $\mathrm{C}_{0} \mathrm{~L}_{15}$. Compared with $\mathrm{C}_{0} \mathrm{~L}_{15}$ before tribology testing, $\mathrm{C}_{0} \mathrm{~L}_{15}$ after tribology testing appears to have diffraction peaks of $\mathrm{Al}_{2} \mathrm{O}_{3}$ and $\mathrm{SiO}_{2}$, and the new diffraction peaks of $\mathrm{LaAlO}_{3}, \mathrm{Ba}_{18} \mathrm{Al}_{12} \mathrm{O}_{36}$ and $\mathrm{Al}_{2}\left(\mathrm{SO}_{4}\right)_{3}$, while the diffraction peaks for the $\mathrm{La}_{2} \mathrm{O}_{3}$ and $\mathrm{BaSO}_{4}$ phase disappear, suggesting that the chemical reaction occurs during the friction and wear processes. 


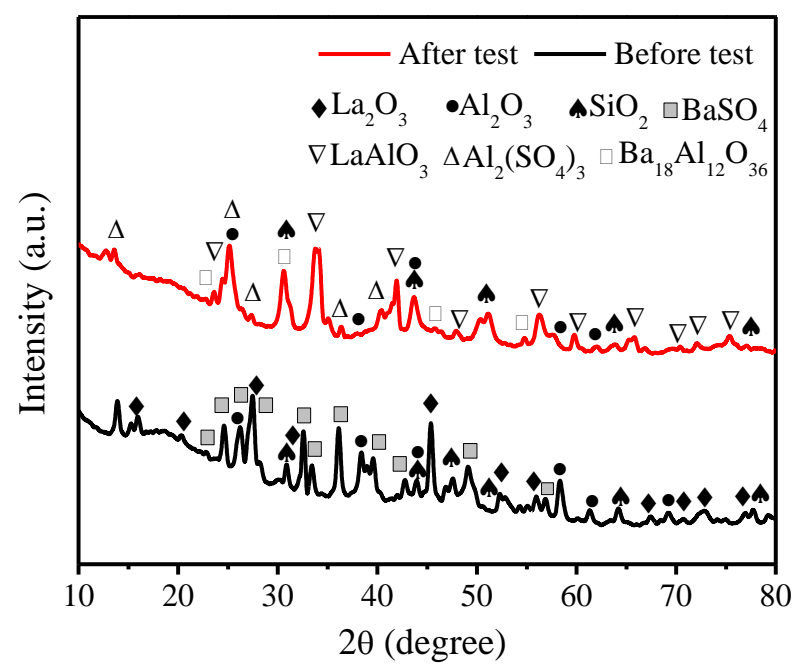

Figure 10. XRD patterns of $\mathrm{C}_{0} \mathrm{~L}_{15}$ before and after tribology testing.

The friction and wear processes of the brake composites are extremely complex dynamic processes, since several interactions such as physical, chemical, and mechanical are simultaneously operative. Under the interaction of external force, chemistry, heat and rare earth lanthanum oxide with excellent chemical activity, the chemical reaction occurs among components. The reaction between $\mathrm{La}_{2} \mathrm{O}_{3}$ and $\mathrm{Al}_{2} \mathrm{O}_{3}$ can form $\mathrm{LaAlO}_{3}$. The chemical equation can be expressed as

$$
\mathrm{La}_{2} \mathrm{O}_{3}+2 \mathrm{Al}_{2} \mathrm{O}_{3} \stackrel{\Delta}{\rightarrow} 2 \mathrm{LaAlO}_{3}
$$

$\mathrm{BaSO}_{4}$ reacting with $\mathrm{Al}_{2} \mathrm{O}_{3}$ yields $\mathrm{Ba}_{18} \mathrm{Al}_{12} \mathrm{O}_{36}$ and $\mathrm{Al}_{2}\left(\mathrm{SO}_{4}\right)_{3}$. The chemical equation can be given by

$$
18 \mathrm{BaSO}_{4}+12 \mathrm{Al}_{2} \mathrm{O}_{3} \stackrel{\Delta}{\rightarrow} \mathrm{Ba}_{18} \mathrm{Al}_{12} \mathrm{O}_{36}+6 \mathrm{Al}_{2}\left(\mathrm{SO}_{4}\right)_{3}
$$

Compared with $\mathrm{La}_{2} \mathrm{O}_{3}, \mathrm{LaAlO}_{3}$ shows hexagonal crystals as well [39], which is similar to layered structures with lower melting points and lower hardness, and is more conducive to the formation of continuous and compacted friction films. $\mathrm{LaAlO}_{3}$ can be used in functional ceramics with high quality [40]. The generated $\mathrm{Ba}_{18} \mathrm{Al}_{12} \mathrm{O}_{36}$ belongs to the barium aluminate salts, which can be used as inorganic bonding materials, and has excellent high temperature properties [41]. The produced $\mathrm{Al}_{2} \mathrm{SO}_{4}$ has a melting point of $770{ }^{\circ} \mathrm{C}$, and can be used as an inorganic binder [42]. Given the above, the addition of $\mathrm{La}_{2} \mathrm{O}_{3}$ to the brake composites can lead to the reaction between $\mathrm{La}_{2} \mathrm{O}_{3}$ and $\mathrm{Al}_{2} \mathrm{O}_{3}$ to form $\mathrm{LaAlO}_{3}$, and lead to the reaction between $\mathrm{Al}_{2} \mathrm{O}_{3}$ and $\mathrm{BaSO}_{4}$ to produce $\mathrm{Ba}_{18} \mathrm{Al}_{12} \mathrm{O}_{36}$ and $\mathrm{Al}_{2} \mathrm{SO}_{4}$ during the friction and wear processes. This process is similar to the mechanism of sintering ceramics that enables the previously accumulated inorganic filler to bind together with chemical bonds, which can effectively improve the tribological properties of the brake composites at elevated temperature. The traditional resin-based brake materials will suffer from the decrease of friction coefficient at elevated temperature, owing to the limited heat resistance of the phenolic resin. As previously mentioned, $\mu_{\text {hot }}$ for all developed brake composites containing $\mathrm{La}_{2} \mathrm{O}_{3}$ was higher than that of $\mu_{\text {normal }}$. This tribological property of the composites is opposite to the traditional resin-based brake composites, and is in accordance with the property of the ceramic brake composites at elevated temperature $[43,44]$. Overall, the addition of $\mathrm{La}_{2} \mathrm{O}_{3}$ to the brake composites can promote chemical reaction between inorganic fillers, and act as an inorganic binder at elevated temperature, which can effectively improve the tribological properties of the brake composites.

\section{Conclusions}

This study aims to use its findings as a guide to the development of $\mathrm{Cu}$-free, metal-free and eco-friendly brake composites. The results obtained are useful for understanding the mechanism of 
the role of $\mathrm{La}_{2} \mathrm{O}_{3}$ in polymeric matrix brake composites to replace $\mathrm{Cu}$. $\mathrm{Cu}$ can be successfully replaced by $\mathrm{La}_{2} \mathrm{O}_{3}$ in brake composites. The results are summarized as follows:

1. For almost all important properties (e.g., $\mu_{\text {normal }}, \mu_{\text {hot }}, \Delta \mu, \mu_{\text {fade }}, \mu_{\text {recovery }}$, fade $\%$ and recovery $\%$ ), $\mathrm{Cu}$-free brake composites $\left(\mathrm{C}_{0} \mathrm{~L}_{15}\right)$ performed significantly better than the brake composites containing $\mathrm{Cu}$ without $\mathrm{La}_{2} \mathrm{O}_{3}\left(\mathrm{C}_{15} \mathrm{~L}_{0}\right)$, while the $\mathrm{Cu}$-contained brake composites $\left(\mathrm{C}_{15} \mathrm{~L}_{0}\right)$ are slightly superior in thermal performance and wear resistance.

2. $\mathrm{La}_{2} \mathrm{O}_{3}$ has synergistic effects with $\mathrm{Cu}$ in the composites, which can further improve the thermal performance and wear resistance of the brake composites. Composites containing both $\mathrm{Cu}$ and $\mathrm{La}_{2} \mathrm{O}_{3}$ have better thermal and wear performance than those containing only $\mathrm{Cu}$ or $\mathrm{La}_{2} \mathrm{O}_{3}$.

3. The addition of $\mathrm{La}_{2} \mathrm{O}_{3}$ in brake composites improves the heat resistance function compared to the addition of $\mathrm{Cu}$. The friction coefficient $(\mu)$ increases with the increase in temperature, which is different from the traditional properties of the brake composites and proves the best heating fade resistance of the developed copper -free brake composites.

4. Compared with the addition of $\mathrm{Cu}$ in brake composites, $\mathrm{La}_{2} \mathrm{O}_{3}$ is more conducive to the formation of continuous and compacted friction films and transfer films and causes the decrease in surface roughness, which is beneficial to the tribological properties of the brake composites.

5. The addition of $\mathrm{La}_{2} \mathrm{O}_{3}$ to the brake composites can cause the reaction between $\mathrm{La}_{2} \mathrm{O}_{3}$ and $\mathrm{Al}_{2} \mathrm{O}_{3}$ to form $\mathrm{LaAlO}_{3}$, and cause the reaction between $\mathrm{Al}_{2} \mathrm{O}_{3}$ and $\mathrm{BaSO}_{4}$ to produce $\mathrm{Ba}_{18} \mathrm{Al}_{12} \mathrm{O}_{36}$ and $\mathrm{Al}_{2} \mathrm{SO}_{4}$ during the friction and wear processes. This process is similar to the mechanism of sintering ceramics, which can effectively improve the tribological properties of the brake composites at elevated temperature.

Supplementary Materials: The following are available online at http:/ /www.mdpi.com/2073-4360/10/9/1027/ s1, Figure S1: EDS spectrums of the worn surfaces of the brake composites: (a) $\mathrm{C}_{10} \mathrm{~L}_{5}$; (b) $\mathrm{C}_{5} \mathrm{~L}_{10}$; (c) $\mathrm{C}_{15} \mathrm{~L}_{0}$; (d) $\mathrm{C}_{0} \mathrm{~L}_{15}$.

Author Contributions: C.G. and K.Z. have conceived the idea and supervised the whole procedure. K.Z. wrote the paper and contributed to the whole process of the preparation of samples, experimental measurement, and interpretation of results. F.H. contributed to the process of the preparation of samples. Y.L. contributed to the discussion of the experimental results and all authors provided feedback.

Funding: The authors gratefully acknowledge the financial support of the National Science Foundation of China (Grant No. 51375094) and Fujian Provincial Collaborative Innovation Center for High-end Equipment Manufacturing (No. 0020-50006103).

Acknowledgments: The authors are grateful to the Haixi Institutes of Chinese Academy of Sciences for the support of thermal performance testing of the brake composites.

Conflicts of Interest: The authors declare no conflict of interest.

\section{References}

1. Hjortenkrans, D.; Bergbäck, B.; Häggerud, A. New metal emission patterns in road traffic environments. Environ. Monit. Assess. 2006, 117, 85-98. [CrossRef] [PubMed]

2. Kukutschová, J.; Roubíek, V.; Malachová, K.; Pavlícková, Z.; Holua, R.; Kubaková, J.; Mika, V.; MacCrimmon, D.; Filip, P. Wear mechanism in automotive brake composites, wear debris and its potential environmental impact. Wear 2009, 267, 807-817. [CrossRef]

3. Hagino, H.; Oyama, M.; Sasaki, S. Laboratory testing of airborne brake wear particle emissions using a dynamometer system under urban city driving cycles. Atmos. Environ. 2016, 131, 269-278. [CrossRef]

4. Copper-Free Brakes Initiative. Available online: http:/ / www.copperfreebrakes.org (accessed on 19 October 2017).

5. Kumar, M.; Bijwe, J. Non-asbestos organic (NAO) friction composites: Role of copper; its shape and amount. Wear 2011, 270, 269-280. [CrossRef]

6. Kumar, M.; Bijwe, J. Optimized selection of metallic fillers for best combination of performance properties of friction materials: A comprehensive study. Wear 2013, 303, 569-583. [CrossRef]

7. Kumar, M.; Bijwe, J. NAO friction materials with various metal powders: Tribological evaluation on full-scale inertia dynamometer. Wear 2010, 269, 826-837. [CrossRef] 
8. Kumar, M.; Bijwe, J. Role of different metallic fillers in non-asbestos organic (NAO) friction composites for controlling sensitivity of coefficient of friction to load and speed. Tribol. Int. 2010, 43, 965-974. [CrossRef]

9. Kim, S.J.; Lee, J.Y.; Han, J.M.; Kim, Y.C.; Park, H.D.; Sung, S.H.; Lee, J.J.; Cha, J.H.; Jo, J.H. The role of copper on the friction and wear performance of automotive brake composites. SAE Int. J. Mater. Manuf. 2012, 5, 9-18. [CrossRef]

10. Österlea, W.; Prietzela, C.; Kloßa, H.; Dmitriev, A.I. On the role of copper in brake composites. Tribol. Int. 2010, 43, 2317-2326. [CrossRef]

11. Menezes, P.L. Study of friction and transfer layer formation in copper-steel tribo-system: Role of surface texture and roughness parameters. Tribol. Trans. 2009, 52, 6-11. [CrossRef]

12. Lee, P.W.; Filip, P. Friction and wear of $\mathrm{Cu}$-free and $\mathrm{Sb}$-free environmental friendly automotive brake composites. Wear 2013, 302, 1404-1413. [CrossRef]

13. Aranganathan, N.; Bijwe, J. Development of copper-free eco-friendly brake-friction material using novel ingredients. Wear 2016, 352-353, 79-91. [CrossRef]

14. Subramanian, V. Friction Material for Brakes-A Copper and Titanate Free Nonasbestos Friction Material. U.S. Patent Application No. 20100084232A1, 8 April 2010.

15. Chen, H.; Paul, H.G. Copper-Free Friction Material for Brake Pads. C.N. Patent Application No. 102971550A, 13 March 2013.

16. Zhang, J.Z. Copper-Free Friction Material Composition for Brake Pads. U.S. Patent Application No. 2014357758A1, 4 December 2014.

17. Cox, R.L. Copper Free Friction Material Composition. U.S. Patent Application No. 20150369321A1, 24 December 2015.

18. Gilardi, R.; Alzati, L.; Thiam, M.; Brunel, J.; Desplanques, Y.; Dufrénoy, P.; Sharma, S.; Bijwe, J. Copper substitution and noise reduction in brake pads: Graphite type selection. Materials 2012, 5, 2258-2269. [CrossRef]

19. Aranganathan, N.; Bijwe, J. Special grade of graphite in NAO friction materials for possible replacement of copper. Wear 2015, 330-331, 515-523. [CrossRef]

20. Peng, G.; Zheng, D.; Cheng, C.; Zhang, J.; Zhang, H. Effect of rare-earth addition on morphotropic phase boundary and relaxation behavior of the PNN-PZT ceramics. J. Alloy. Compd. 2017, 693, 1250-1256. [CrossRef]

21. Cheng, X.H.; Shang-Guan, Q.Q. Effect of rare earths on mechanical and tribological properties of carbon fibers reinforced PTFE composite. Tribol. Lett. 2006, 21, 153-159. [CrossRef]

22. Bao, D.D.; Cheng, X.H. Tribological behavior of polytetrafluroethylene composites filled with rare earths treated carbon fiber under dry friction condition. Tribology 2006, 26, 135-139.

23. Zhang, S.H.; Wang, S.X.; Huang, Z.H. A kinetic analysis of thermal decomposition of polyaniline and its composites with rare earth oxides. J. Therm. Anal. Calorim. 2015, 119, 1853-1860. [CrossRef]

24. Sliney, H.E. Rare Earth Fluorides and Oxides-An Exploratory Study of Their Uses as Solid Lubricants at Temperatures to $1800^{\circ} \mathrm{F}\left(1000^{\circ} \mathrm{C}\right)$; TN D-5301; NASA: Washington, DC, USA, 1969.

25. Zheng, K.; Gao, C.; He, F.; Lin, Y.; Jiang, L. Tribological performance of resin-based brake friction materials modified with $\mathrm{La}_{2} \mathrm{O}_{3}$. China Mech. Eng. 2018, 29, 666-673.

26. Zheng, K.; Gao, C.; He, F.; Lin, Y.; Lei, Y. Tribological performance of rare earth modified resin matrix brake materials under different conditions. Trans. Mater. Heat Treat. 2017, 38, 133-140.

27. JIS D 4418-1996. Test Procedure of Porosity for Brake Linings and Pads of Automobiles; Japanese Industrial Standards Committee: Tokyo, Japan, 1996.

28. ISO 2039-2:1987. Plastics_Determination of Hardness_Part 2: Rockwell Hardness; International Organization for Standardization: Geneva, Switzerland, 1987.

29. ISO 179-1:2010. Plastics_Determination of Charpy Impact Properties—Part 1: Non-Instrumented Impact Test; International Organization for Standardization: Geneva, Switzerland, 2010.

30. ISO 527-4. Plastics-Determination of Tensile Properties; International Organization for Standardization: Geneva, Switzerland, 1997.

31. ASTM D5470-06. Standard Test Method for Thermal Transmission Properties of Thermally Conductive Electrical Insulation Materials; American Society for Testing and Materials: West Conshohocken, PA, USA, 2011.

32. SAE J661-1997. Brake Lining Quality Test Procedure; Society of Automotive Engineers: Pittsburgh, PA, USA, 1997. 
33. Yen, B.K.; Ishihara, T. On temperature-dependent tribological regimes and oxidation of carbon-carbon composites up to $1800^{\circ} \mathrm{C}$. Wear 1996, 196, 254-262. [CrossRef]

34. Evans, A.G.; Marshall, D.B. Wear Mechanisms in Ceramics. In Fundamental of Friction and Wear of Materials; Rigney, D.A., Ed.; American Society for Metals: Geauga County, OH, USA, 1981; pp. 439-452.

35. Filip, P.; Weiss, Z.; Rafaja, D. On friction layer formation in polymer matrix composite materials for brake applications. Wear 2002, 252, 189-198. [CrossRef]

36. Rhee, S.K.; Jacko, M.G.; Tsang, P.H.S. The role of friction film in friction, wear and noise of automotive brakes. Wear 1991, 146, 89-97. [CrossRef]

37. Österle, W.; Urban, I. Friction layers and friction films on PMC brake pads. Wear 2004, 257, $215-226$. [CrossRef]

38. Cho, M.H.; Cho, K.H.; Kim, S.J.; Kim, D.H.; Jang, H. The role of transfer layers on friction characteristics in the sliding interface between friction materials against gray iron brake disks. Tribol. Lett. 2005, 20, 101-108. [CrossRef]

39. Dicks, O.A.; Shluger, A.L.; Sushko, P.V.; Littlewood, P.B. Spectroscopic properties of oxygen vacancies in $\mathrm{LaAlO}_{3}$. Phys. Rev. B 2017, 93, 134114. [CrossRef]

40. Huang, C.; Shen, C.; Qiu, T. Research on Microwave Dielectric Properties of $\mathrm{LaAlO}_{3}-\mathrm{SrTiO}_{3}$ Ceramics with High Quality Factor. J. Synth. Cryst. 2014, 43, 2056-2061.

41. Li, J.; Wang, Z.; Wang, X.; Liu, H.; Ma, Y. Synthesis and hydration characteristics of barium aluminate. J. Ceram. 2018, 39, 69-72.

42. Yang, K.; Cheng, X.; Hao, E. Study on the aluminium sulphate-phosphate inorganic adhesive. China Ceram. 2009, 45, 43-45.

43. Nilov, A.; Kulik, V.; Garshin, A. Analysis of friction materials and technologies developed to make brake shoes for heavily loaded brake systems with disks made of a ceramic composite. Refract. Ind. Ceram. 2015, 56, 402-412. [CrossRef]

44. Ralph, R.; Gerd, S.; Walter, K. Integration of CMC brake disks in automotive brake systems. Int. J. Appl. Ceram. Technol. 2012, 9, 712-724. 